\title{
Impact of the global COVID-19 pandemic on the use of local government funds
}

\author{
Viktor Soltes ${ }^{1, *}$, Jana Stofkova ${ }^{2}$, and Jakub Durica ${ }^{1}$ \\ ${ }^{1}$ University of Zilina, Faculty of Security Engineering, Univerzitna 1, 01026 Zilina, Slovakia \\ ${ }^{2}$ University of Zilina, Faculty of Operation and Economics of Transport and Communications, \\ Univerzitna 1, 01026 Zilina, Slovakia
}

\begin{abstract}
Research background: Municipalities, as entities of local government, finance the performed activities on the basis of the budget, which has a program structure. However, due to the global COVID-19 pandemic, municipal incomes have declined. Municipalities therefore had to adjust their budgets and reduce expenditures, which could disrupt several processes in municipalities.

Purpose of the article: The main aim of the paper is to analyse the budgets of selected local government entities and assess the impact of the COVID19 pandemic on the use of funds by municipalities with an emphasis on the security area.

Methods: In order to assess the impact of the COVID-19 pandemic on the use of funds by municipalities, a detailed analysis of the budgets and final accounts of selected municipalities will be carried out. The amount of income and expenditure in these municipalities before and after the outbreak of the COVID-19 pandemic will be examined. For this purpose, basic scientific methods and methods of mathematical statistics will be used.

Findings \& Value added: Based on the assessment of the COVID-19 pandemic impact on the budgets of municipalities, it will be possible to determine the activities that experienced the largest revenue shortfalls due to the fact that the municipalities could not finance them from their revenues. The contribution of the paper will be recommendations that should prevent such situations in the future and thus prevent the amount of damage that has been recorded as a result of the loss of income of municipalities.
\end{abstract}

Keywords: COVID-19 pandemic; municipality; financing; security

JEL Classification: $H 72 ; H 76$; $F 63$

\footnotetext{
*Corresponding author: viktor.soltes@uniza.sk
} 


\section{Introduction}

The economic management of any entity is governed by a budget. However, public administration entities must follow the laws and other generally binding regulations that regulate the budget process of public administration when compiling and implementing the budget. The revenues and expenditures of the public administration (and thus the state) are affected by a myriad of aspects that occur within the state, but which also occur outside the state (Loucanova et al., 2021). Globalization has also brought with it the interconnection of national economies, and therefore the geopolitical situation to a large extent also affects the domestic socio-economic situation of individual countries. According to Stofkova and Sukalova (2020), the occurrence of the global economic crisis in the years 2008 - 2014 only proved this interconnectedness of individual states from the economic area. In 2020, however, the world entered another global crisis, which wasn't caused by the failure of banks and the economic system, but caused by the global pandemic. This pandemic paralyzed the economies of all countries of the world, including Slovakia (Sventekova et al., 2021). This unprecedented situation affected not only the overall management of the state and the fulfilment of all performed tasks of the state, but also the economy of the state. The impact of the COVID-19 pandemic on the private sector was dealt with a number of expert articles and discussions, and individual countries have chosen various more or less effective approaches to addressing the unfavourable situation in the private sector (Polorecka et al., 2021). The impact of the COVID-19 pandemic on the lowest level of public administration local self-government, however, is dealt with only minimally by experts, while municipalities, as the basic unit of territorial self-government, can be considered as entities most affected by the COVID-19 pandemic, however, state measures to assist these entities can be considered as a minimal (Valaskova et al., 2021).

The public administration budget is a medium-term economic instrument of the state's financial policy, which is based on the principle of multi-annual budgeting. The public administration budget is composed of the state budget and the budgets of other public administration entities for a period of at least three budget years (Kliestik et al., 2020). The budgeted revenues and expenditures of the state budget and the budgets of other public administration entities for the first year are binding, for the second and third years they are indicative and will be specified in the next budget year, but only on the basis of exceptionally justified cases.

The process of creating a public administration budget can be divided into two main steps. The first step includes the elaboration of the starting points of the public administration budget for three financial years and their submission by the end of March of the current year for the government meeting (Gruenbichler et al., 2021). The second step of work on the public administration budget begins after the approval of the starting points in the government. The Ministry of Finance of the Slovak Republic prepares a draft public administration budget, within which it prepares a draft state budget and a draft summary of the budgets of other public administration entities. The draft public administration budget is subsequently submitted by the Ministry of Finance of the Slovak Republic to the government by 15 August of the current year. The government usually decides on the draft public administration budget by 30 September of the current year. The Government submits a draft public administration budget to the National Council of the Slovak Republic by 15 October of the current year.

As part of the public finance reform, several projects were formulated in 1999, including the introduction of results-oriented budgeting, i.e., program budgeting (Ginevicius et al., 2020). It is a system based on planning the tasks and activities of the government in connection with its priorities and allocation of available resources to programs, with emphasis on the results and efficiency of spending budget funds (Kubas et al., 2017). Figure 1 shows the current public administration expenditure in 2021 on individual programs. 


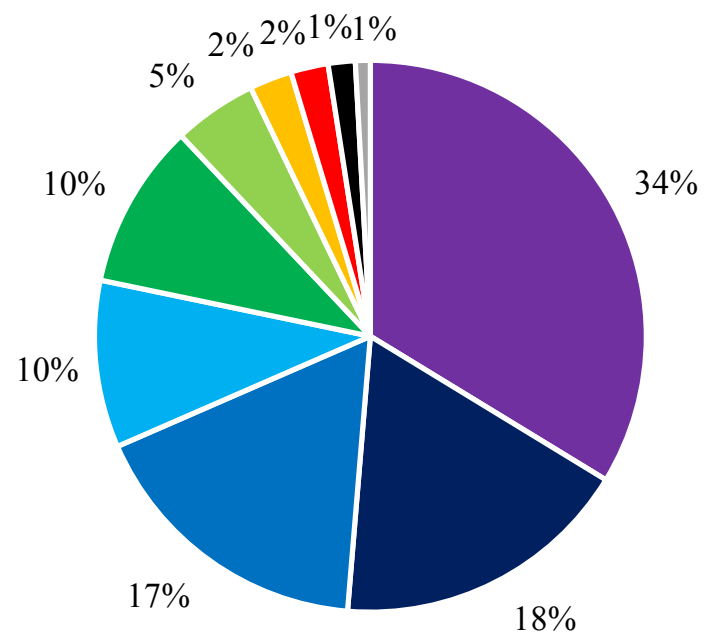

Figure 1. State expenditures in 2021.

Source: Ministry of Finance of the Slovak Republic (2021)

The total expenditures of public administration in Slovakia in 2021 amount to 46,734.59 mil. $€$. Among the individual programs, the state invested the highest amount of funds in social security (38\%). The second most funded public administration budget program is the general public services (18\%). Expenditure on these two programs represents the majority of all public administration budget expenditure. In the long run, this redistribution of public administration expenditure can be considered standard, and thus it can be stated that the COVID-19 pandemic did not have a significant impact on the redistribution of public administration expenditure to individual programs.

The budget process of territorial self-government is regulated by Act no. 523/2004 Coll. on Budgetary Rules of Public Administration and of Change and Amendment of Particular Acts and Act no. 583/2004 Coll. on Budget Rules of the Regional Self-Administration and of Change and Amendment of Particular Acts. In 2006, the government set a goal to implement program budgeting at all levels of public administration. As of 1 September 2007, an amendment to the Act 583/2004 on Budget Rules of the Regional Self-Administration entered into force, according to which program budgeting is introduced in local and regional self-government, starting with the budget for 2009 to 2011.

The budget of the municipality, as the basic unit of territorial self-government, is part of the public administration budget and is the basic instrument of financial management in the relevant budget year, which governs the financing of tasks and functions of the municipality in the relevant budget year. The municipality's budget contains the revenues and expenditures of the municipality and also contains the intentions and goals that the municipality will implement from the expenditures of the municipality's budget (i.e., municipality program).

\section{Methodology}

After the end of the budget year, the municipality processes the data on budget management in the final account of the municipality. In order to determine the impact of the COVID-19 pandemic on the expenditures of municipalities and cities, the final accounts of eight regional capital cities will be analysed. Given that all municipalities have recently had to deal with resolving the COVID-19 pandemic and ensuring the protection of the lives and health of their 
citizens, emphasis will be placed on analysing the expenditure of selected cities on securityrelated tasks.

The final accounts of selected cities for 2018-2020 will be analysed, given that 2018 represents the standard year unaffected by the COVID-19 pandemic, 2019 represents the year when the first cases of the COVID-19 pandemic appeared in Slovakia and 2020 represents the year, during which the COVID-19 pandemic persisted in Slovakia.

Basic scientific methods will be used to analyse the collected data, including data analysis and synthesis, as well as induction and deduction. These basic scientific methods will be supplemented by basic methods of mathematical statistics (Boros et al., 2019). The data analysed in this way will point out the impact of the COVID-19 pandemic on the expenditures of selected cities with an emphasis on the protection of the lives and health of their citizens.

\section{Results and Discussions}

Municipalities ensure the fulfilment of their tasks primarily from their own tax and non-tax revenues. However, the state by Act no. 416/2001 Coll. on the Transfer of Certain Powers from State Administration Authorities to Municipalities and Higher Territorial Units, had transferred certain powers to municipalities. Additional subsidies were provided to municipalities from the state budget to finance the transferred performance of state administration and to perform other tasks related to regional development, environmental protection and the implementation of projects co-financed from European Union resources. Given that the revenues, and thus also the expenditures of cities, depend on the size of cities (city population), for comparison it is necessary to state the expenditures of cities according to the number of their inhabitants. Figure 2 shows the amount of total expenditure of selected cities in the years 2018 - 2020 per inhabitant.

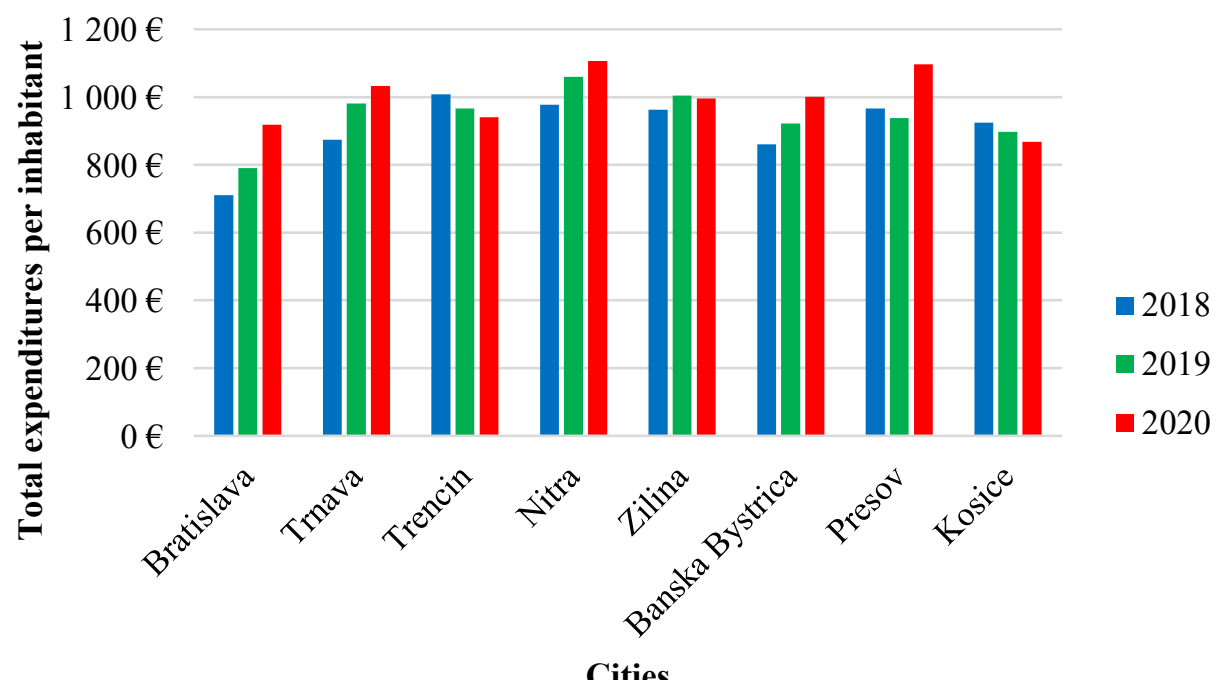

Figure 2. Total expenditures of selected cities per inhabitant in 2018-2020.

Source: Final accounts of cities (2021)

The total expenditure of cities per inhabitant develops steadily in the observed period and no significant fluctuations are noticeable. The annual increase in expenditures can be observed in the cities of Bratislava, Trnava, Nitra and Banska Bystrica. The annual decline 
can be noticed in the cities of Trencin and Kosice. Expenditures of the Zilina city did not fluctuate and can be considered stable. In the case of the Presov city, it can be noted that in 2019 its expenditure per inhabitant decreased slightly compared to 2018, while in 2020 there was a significant increase in expenditure compared to 2019.

As already mentioned, due to the COVID-19 pandemic, it was necessary for cities to ensure the protection of the lives and health of their citizens. That is why it is necessary to analyse the share of expenditures of selected cities on security. Figure 3 shows the share of expenditures of selected cities invested in security in the years 2018 - 2020 in relation to the total expenditures of these cities.

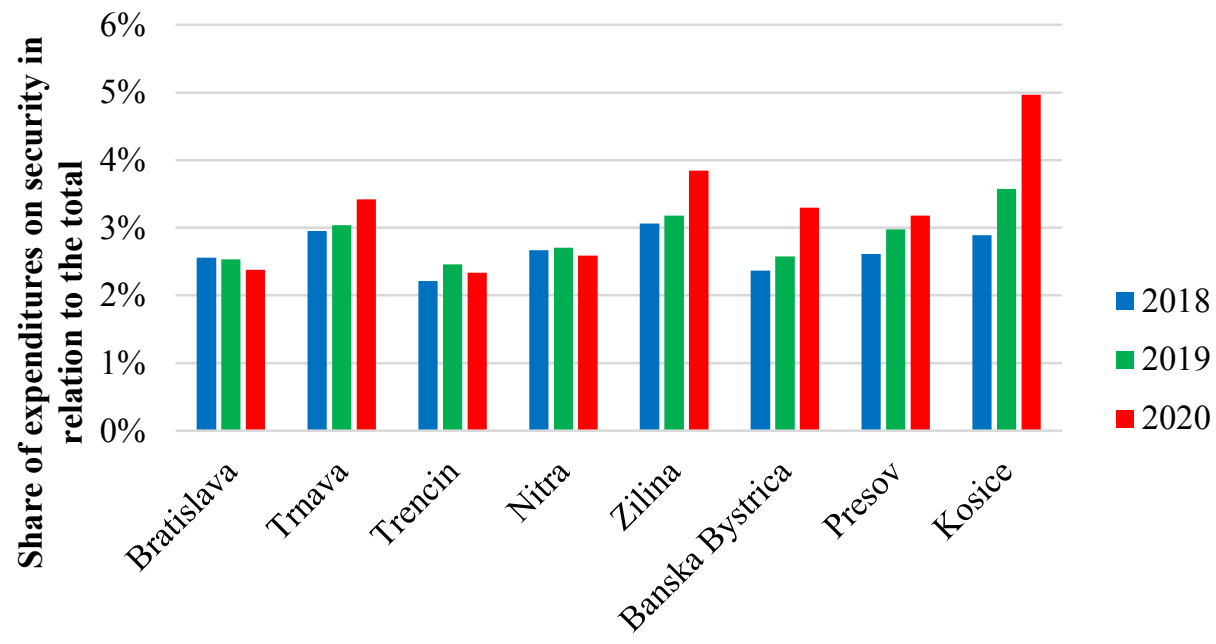

Cities

Figure 3. The share of expenditures on security of selected cities in relation to total expenditures in 2018-2020.

Source: Final accounts of cities (2021)

Expenditure on security in selected cities represents approximately 3 percent of the total expenditure of these cities. The annual increase in security expenditures in relation to total expenditures can be seen in the cities of Trnava, Zilina, Banska Bystrica, Presov and Kosice. In other cities - Bratislava, Trencin and Nitra, the share of expenditures in the field of security is stabilized with respect to their total expenditures. With the exception of the cities of Zilina, Banska Bystrica and Kosice, where a slightly more significant increase in security expenditures can be observed in 2020 compared to their total expenditures in 2019. The COVID-19 pandemic did not significantly affect the amount of funds invested in security.

Another aspect from which it is possible to examine cities' expenditures on security is to examine them in terms of population. The development of security expenditure in relation to total cities expenditure may not correlate with the development of this expenditure per inhabitant. Figure 4 shows the development of the amount of funds of selected cities invested in the field of security in the years 2018 - 2020 per inhabitant. 


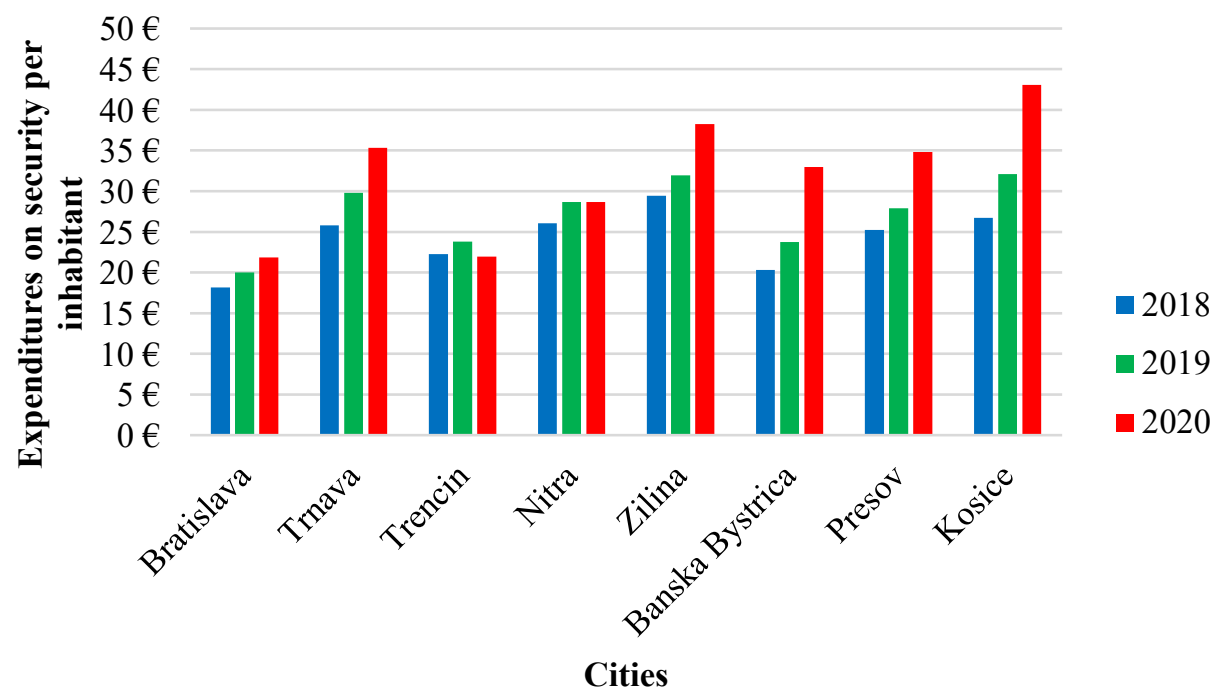

Figure 4. Expenditures on security of selected cities per inhabitant in 2018-2020.

Source: Final accounts of cities (2021)

With the exception of two cities - Trencin and Nitra, in all selected cities in the observed period, there was an annual increase in the amount of funds invested by these cities in security per inhabitant. A more significant increase in such recalculated expenditures can be noticed in 2020 in the cities of Zilina, Banska Bystrica, Presov and Kosice. In the cities of Bratislava and Trnava, the increase compared to the previous period is steady. In 2020, the city of Trencin recorded a slight decrease in security expenditures per inhabitant compared to 2019. In the city of Nitra, the situation can be considered stable from this point of view.

\section{Conclusions}

Public administration entities, including municipalities, perform important tasks related to ensuring the basic functioning of the state, including ensuring the protection of life and health of citizens. The financing of these basic tasks of the state depends on the economic situation of the state, which is influenced by various local as well as global aspects, which include, in particular, globalization and the interconnectedness of economies. The COVID-19 pandemic has crippled the world and hit every country economically. States have taken measures to prevent the spread of the pandemic and to protect the lives and health of citizens, to the detriment of the country's socio-economic development. Although measures were taken from the central level of states to support the business sector (private sector), support for municipalities (public sector) was minimal, while municipalities are currently an important aspect of the implementation of anti-pandemic measures.

An analysis of the expenditures of selected cities in the years 2018 - 2020 revealed that the COVID-19 pandemic did not significantly affect the cities. Total cities expenditures have followed a trend. Given that the COVID-19 pandemic threatened citizens 'security in 2019 and 2020 in particular, it was necessary to examine how the measures implemented by cities in the area of protection of citizens' lives and health were reflected in their expenditures. Although no significant changes in the development of cities security funding were observed in the long run, in 2020 it was possible to observe a more significant increase in this expenditure in half of the selected cities compared to the current periods of previous years. 


\section{Acknowledgements}

This paper was supported by project VEGA 1/0768/19 and VEGA 1/0518/19.

\section{References}

1. Act No. 416/2001 Coll. on the Transfer of Certain Powers from State Administration Authorities to Municipalities and Higher Territorial Units

2. Act No. 583/2004 Coll. on Budget Rules of the Regional Self-Administration and of Change and Amendment of Particular Acts

3. Boros, M., Zvakova, Z., \& Halaj, M. (2019). Required competencies of security managers for decision-making. Proceedings of International Technology, Education and Development Conference (INTED), Spain, 13, (pp. 3918-3923).

4. Final accounts of Banska Bystrica, Bratislava, Kosice, Nitra, Presov, Trencin, Trnava, Zilina

5. Ginevicius, R., Kliestik, T., Stasiukynas, A., \& Suhajda, K. (2020). The Impact of National Economic Development on the Shadow Economy. Journal of Competitiveness 12(4), 39-55.

6. Gruenbichler, R., Klucka, J., Haviernikova, K., \& Strelcova, S. (2021). Business Performance Management in Small and Medium-Sized Enterprises in the Slovak Republic: An Integrated Three-Phase-Framework for Implementation. Journal of Competitiveness 13(1), 42-58.

7. Kliestik, T., Valaskova, K., Nica, E., Kovacova, M., \& Lazaroiu, G. (2020). Advanced methods of earnings management: monotonic trends and change-points under spotlight in the Visegrad countries. Oeconomia copernicana, 11(2), 371-400.

8. Kubas, J., Stofkova, Z., \& Misik, J. (2017). The impact of fiscal decentralization on public administration. Proceedings of International conference of Central-BohemiaUniversity (CBUIC) - Innovations inScience and Education, Czechia, 5, 242-246.

9. Loucanova, E., Supin, M., Corejova, T., Repkova-Stofkova, K., Supinova, M., Stofkova, Z., \& Olsiakova, M. (2021). Sustainability and Branding: An Integrated Perspective of Eco-innovation and Brand. Sustainability, 13(2), Article 732.

10. Ministry of finance of the Slovak republic. (2021, September 22). Public administration budget. Available at: https://rozpocet.sk/web/\#/prehlad

11. Ministry of finance of the Slovak republic. (2021, October 1). Basic framework for creating a public administration budget. Available at: https://www.mfsr.sk/sk/financie/verejne-financie/regulacny-komplex-pravnychnoriem-metodickych-postupov-z-oblasti-rozpoctoveho-procesu/tvorba-viacrocnehorozpoctu-verejnej-spravy/zakladny-ramec-tvorbu-rozpoctu-verejnej-spravy/

12. Polorecka, M., Kubas, J., Danihelka, P., Petrlova, K., Repkova-Stofkova, K., \& Buganova, K. (2021). Use of Software on Modeling Hazardous Substance Release as a Support Tool for Crisis Management. Sustainability, 13(1), Article 438.

13. Stofkova, Z., \& Sukalova, V. (2020). Sustainable Development of Human Resources in Globalization Period. Sustainability, 12(18), Article 7681.

14. Sventekova, E., Urbancova, Z., \& Holla, K. (2021). Assessment of the Vulnerability of Selected Key Elements of Rail Transport. Slovak Case Study. Applied Sciences-Basel 11(13), 6174-6174.

15. Valaskova, K., Durana, P., \& Adamko, P. (2021). Changes in Consumers' Purchase Patterns as a Consequence of the COVID-19 Pandemic. Mathematics 9(15), 1788-1788. 